\title{
TINJAUAN HUKUM DOKTER YANG BERKOLUSI DENGAN PERUSAHAAN FARMASI DALAM MERESEPKAN OBAT ${ }^{*}$
}

\author{
Yenny Fitri. Z \\ Sekolah Tinggi Ilmu Hukum Putri Maharaja Payakumbuh \\ Napar, Kec. Payakumbuh Utara, Kota Payakumbuh \\ e-mail: yennyfitri@ rocketmail.com
}

\begin{abstract}
At the end of 2015, the Tempo Magazine investigation team released a gratification case conducted by the pharmaceutical company Interbat against 2,125 doctors. The gratuities are suspected to be one of the reasons that influence doctors in prescribing drugs to patients. Funds used by pharmaceutical companies to serve doctors can reach 45 percent of drug prices. Therefore, patients must redeem the drug at a more expensive price. Moving from the results of these investigations, the authors are interested to examine criminal rules that can ensnare doctors who receive the gift from pharmaceutical companies. So far, the rule of law governing the prohibition of doctors receiving gifts from Pharmaceutical Companies has not had a deterrent effect. The existing arrangements are in the realm of ethics and administration. As a result, the cooperation of doctors and pharmaceutical companies in prescribing the drug continues and affects the patient's harm. Because in the practice of the physician profession is divided into two, namely private doctors and civil servants, then the formulation of the issues to be discussed in this paper is, First, how the imposition of legal sanctions for private doctors who receive the gift from Pharmaceutical Company Second, how the imposition of legal sanctions for civil servant doctors who receive the gift from Pharmaceutical Company To answer the problem, the author uses normative juridical research method. The results of his research are private doctors who receive the gift from pharmaceutical companies may be subject to Article 3 of Law Number 11 Year 1980 on the Crime of Bribery. As for doctors who have the status of Civil Servants subject to Article 12B of Law Number 31 Year 1999 junto Law Number 20 Year 2001 About Corruption Eradication (Anti-Corruption Law). As a suggestion at the end of the writing, the author wants that the formulation of Article 12B of the AntiCorruption Law be expanded so that it is not limited to civil servants or state officials only. However, pending the improvement of the formulation of Article 12B, the authors recommend that law enforcement still play an active role by using Article 3 of the Anti-Bribery Law to ensnare doctors who receive the gift from ph armaceutical companies.
\end{abstract}

Keyword: Doctors Collusion, Corruption.

\begin{abstract}
Abstrak
Di penghujung tahun 2015, tim investigasi Majalah Tempo merilis adanya kasus gratifikasi yang dilakukan oleh perusahaan farmasi Interbat terhadap 2.125 dokter. Gratifikasi tersebut diduga sebagai salah satu alasan yang mempengaruhi dokter dalam meresepkan obat pada pasien. Dana yang dipakai perusahaan farmasi untuk melayani dokter bisa mencapai 45 persen dari harga obat. Oleh karena itu, pasien harus menebus obat dengan harga yang lebih mahal. Beranjak dari hasil investigasi tersebut, penulis tertarik untuk meneliti aturan pidana yang dapat menjerat dokter yang menerima pemberian dari perusahaan farmasi. Selama ini, aturan hukum yang mengatur larangan dokter menerima pemberian dari Perusahaan Farmasi belum membawa dampak menjerakan. Pengaturan yang ada baru berada di ranah etika dan administrasi. Akibatnya, kerja sama dokter dan perusahaan farmasi dalam meresepkan obat terus berlanjut dan berdampak kerugian bagi pasien. Karena di dalam praktek profesi dokter terbagi dua, yaitu dokter swasta dan dokter pegawai negeri, maka rumusan masalah yang akan dibahas dalam penulisan ini adalah, Pertama, bagaimana penjatuhan sanksi hukum bagi dokter swasta yang menerima pemberian dari
\end{abstract}

${ }^{*}$ Naskah diterima: 28 Februari 2018, direvisi: 11 Maret 2018, disetujui untuk terbit: 28 Maret 2018 
Yenny Fitri. Z: Tinjauan Hukum Dokter Yang Berkolusi Dengan Perusahaan Farmasi ...

Perusahaan Farmasi? Kedua, bagaimana penjatuhan sanksi hukum bagi dokter pegawai negeri yang menerima pemberian dari Perusahaan Farmasi? Untuk menjawab permasalahan tersebut, Penulis menggunakan metode penelitian yuridis normatif. Hasil penelitiannya adalah dokter swasta yang menerima pemberian dari perusahaan farmasi dapat dikenakan Pasal 3 Undang-Undang Nomor 11 Tahun 1980 tentang Tindak Pidana Suap. Sedangkan bagi dokter yang berstatus Pegawai Negeri Sipil dikenakan Pasal 12B Undang-Undang Nomor 31 Tahun 1999 junto Undang-Undang Nomor 20 Tahun 2001 Tentang Pemberantasan Tindak Pidana Korupsi (UU Anti Korupsi). Sebagai saran di akhir penulisan, Penulis menginginkan agar rumusan Pasal 12B UU Anti Korupsi diperluas sehingga tidak terbatas hanya kepada pegawai negeri atau peyelenggara negara semata. Namun sambil menunggu perbaikan rumusan Pasal 12B, Penulis menyarankan agar penegak hukum tetap berperan aktif dengan menggunakan Pasal 3 UU Anti Suap untuk menjerat dokter yang menerima pemberian dari perusahaan farmasi.

Kata kunci: Kolusi Dokter, Korupsi

\section{PENDAHULUAN}

Kesehatan memiliki arti penting karena merupakan hak asasi manusia yang tertuang dalam Undang-Undang Dasar Republik Indonesia Tahun 1945. Pasal 28 $\mathrm{H}$ Konstitusi Indonesia tersebut menyatakan bahwa "setiap orang berhak hidup sejahtera lahir dan batin, bertempat tinggal dan mendapatkan lingkungan hidup yang baik dan sehat serta berhak memperoleh pelayanan kesehatan", sementara Pasal 34 ayat (3) menyatakan "negara bertanggung jawab atas penyediaan fasilitas pelayanan kesehatan dan fasilitas pelayanan umum yang layak".

Arti pentingnya kesehatan juga dituangkan di dalam Rencana Pembangunan Jangka Panjang Nasional (RPJP-N) 2005-2025. Pembangunan kesehatan menurut RPJP-N 2005-2025 diarahkan untuk meningkatkan derajat kesehatan masyarakat melalui peningkatan upaya kesehatan, pembiayaan kesehatan, sumber daya manusia, obat dan perbekalan kesehatan, pemberdayaan masyarakat dan manajemen kesehatan dengan memperhatikan dinamika kependudukan, epidemiologi penyakit, perubahan ekologi dan lingkungan, kemajuan ilmu pengetahuan dan teknologi, serta globalisasi dengan semangat kemitraan, dan kerja sama lintas sektor. ${ }^{1}$

Oleh karena itu, pelayanan kesehatan harus dilakukan oleh tenaga kesehatan dengan penuh tanggung jawab, memiliki etik dan moral yang tinggi, serta keahlian yang terus ditingkatkan mutunya melalui pendidikan dan pelatihan berkelanjutan agar penyelenggaraan upaya kesehatan memenuhi rasa keadilan dan perikemanusiaan serta sesuai dengan perkembangan ilmu pengetahuan dan teknologi kesehatan. $^{2}$

Dokter merupakan tenaga kesehatan yang memegang peran besar dalam upaya kesehatan masyarakat. Melalui pendidikan, pelatihan dan keahlian yang dimilikinya, dokter menjadi profesi mulia karena memenuhi hak dasar manusia di bidang kesehatan. Namun di dalam pelayanan kesehatan, terutama ketika dokter meresepkan obat kepada pasien, ada celah pelanggaran etik yang dapat dilakukan

\footnotetext{
1 Lihat Rencana Pembangunan Jangka Panjang Nasional 2005-2025

${ }^{2}$ Lihat Konsideran Menimbang huruf b dan c Undang-Undang Republik Indonesia Nomor 36 Tahun 2014 tentang Tenaga Kesehatan.
} 
dokter. Ini terlihat dari hasil tim investigasi majalah Tempo di penghujung tahun 2015 yaitu kasus dugaan gratifikasi atas 2.125 dokter yang dilakukan oleh Perusahaan Farmasi Interbat. ${ }^{3}$ Sebagian besar dokter penerima gratifikasi itu berstatus dokter PNS dan bekerja di rumah sakit milik pemerintah. ${ }^{4}$

Berdasarkan data yang dimiliki Tempo, sekitar 131 miliar rupiah dibayarkan PT. Interbat sejak 2013 hingga 2015 kepada dokter. Tujuannya diduga agar dokter meresepkan obat-obatan produksi Interbat. $^{5}$

Salah seorang dokter sekaligus guru besar farmakologi Universitas Gajah Mada, Iwan Dwiprahasto mengatakan bahwa alasan perusahaan farmasi memberikan hadiah dan komisi kepada dokter karena nilai bisnis obat ini sangat menjanjikan. Perusahaan farmasi menggunakan $45 \%$ dana dari harga obat untuk melayani dokter. 6 Maka tidak heran, dengan adanya kolusi dokter dan perusahaan farmasi, pasien harus menebus obat dengan harga yang mahal meskipun sebenarnya pasien dapat memperoleh merk

${ }^{3}$ http://nasional.tempo.co/read/news/2015/11/ 11/173717860/gratifikasi-dokter-menteri-nilaakan-temui-farmasi-dan-idi Diunduh Jum'at, 16 Februari 2018 Pukul 17.00 Wib.

${ }^{4}$ http://nasional.tempo.co/read/news/2015/11/ 11/173717860/gratifikasi-dokter-menteri-nilaakan-temui-farmasi-dan-idi Diunduh Jum'at, 16 Februari 2018 Pukul 17.00 Wib.

${ }^{5}$ http://www.kpk.go.id/id/berita/beritasub/3067-menteri-kesehatan-gandeng-kpk-cegahgratifikasi-dokter Diunduh Jum'at, 16 Februari 2018 Pukul 17.10 Wib.

http://www.kpk.go.id/id/berita/beritasub/3067-menteri-kesehatan-gandeng-kpk-cegahgratifikasi-dokter Diunduh Jum'at, 16 Februari 2018 Pukul 17.10 Wib. obat lain yang lebih murah dengan kualitas obat yang sama.

Sejauh pengetahuan penulis, belum seorang pun dokter yang di jatuhi pidana atas praktek kolusi tersebut. Untuk itu, Penulis ingin melakukan Tinjauan Hukum Dokter yang Berkolusi dengan Perusahaan Farmasi dalam Meresepkan Obat. Tujuannya agar praktek kolusi dalam pemberian pelayanan kesehatan tersebut tidak merugikan masyarakat sebagai pasien. Di dalam praktek, profesi dokter terbagi atas dokter swasta dan dokter pegawai negeri. Penjatuhan pidana atas dokter pegawai negeri tentu berbeda dengan dokter swasta yang menerima pemberian dari perusahaan farmasi. Maka penelitian ini ditujukan untuk mengetahui dan memahami pengaturan hukum yang tepat untuk menjatuhkan pidana terhadap dokter swasta dan dokter pegawai negeri yang menerima pemberian dari perusahaan farmasi.

\section{METODE PENELITIAN}

Penelitian ini merupakan penelitian hukum normatif (normative legal research). Penelitian hukum normatif disebut juga penelitian hukum doctrinal. Pada penelitian hukum normatif, hukum seringkali dikonsepkan sebagai apa yang tertulis dalam peraturan perundangundangan (law in books) atau hukum dikonsepkan sebagai kaidah atau norma yang merupakan patokan berprilaku manusia yang dianggap pantas. ${ }^{7}$

Amiruddin dan Zainal Asikin, th, Pengantar Metode Penelitian Hukum, PT. Raja Grafindo Persada, Jakarta, Hlm. 118 
Yenny Fitri. Z: Tinjauan Hukum Dokter Yang Berkolusi Dengan Perusahaan Farmasi ...

Penelitian hukum normatif dilakukan dengan cara meneliti bahan pustaka atau data sekunder sehingga juga dinamakan penelitian hukum kepustakaan. ${ }^{8}$ Penelitian kepustakaan (Library Reseach) artinya penelitian ini dilakukan dengan membaca karya-karya yang terkait dengan persoalan yang akan dibahas dan dilanjutkan dengan memuat kajian tentang penelitian. ${ }^{9}$

Penelitian hukum normatif atau kepustakaan dalam penelitian ini mencakup penelitian terhadap asas-asas hukum, penelitian terhadap sistematika hukum, penelitian terhadap taraf sinkronisasi vertikal dan horizontal, perbandingan hukum dan sejarah hukum. Selain itu penelitian ini juga mengkaji dan meneliti peraturan perundang-undangan, ${ }^{10}$ yakni peraturan perundang-undangan yang terkait dengan profesi dokter dan larangan menerima pemberian oleh dokter yang bisa mempengaruhi profesionalitas kerja.

Penelitian ini bersifat deskriptif, yaitu penelitian yang dilakukan untuk menguraikan objek penelitiannya, atau penelitian yang bertujuan untuk mendeskripsikan tentang sesuatu hal di daerah tertentu dan pada saat tertentu. ${ }^{11}$ Dalam penelitian hukum deskriptif (descriptive legal study) ini, pemaparan dan penjelasan bertujuan untuk memperoleh gambaran lengkap tentang

\footnotetext{
${ }^{8}$ Soerjono Soekanto dan Sri Mamudji, 2010, Penelitian Hukum Normatif Suatu Tinjauan Singkat, Rajawali Pers, Jakarta, Hlm. 13

9 Mestika Zed, 2007, Metode Penelitian Kepustakaan, Yayasan Obor Indonesia, Jakarta, Hlm. 3

10 Soerjono Soekanto, 1986. Pengantar Penelitian Hukum, UII Press, Jakarta, Hlm. 15

${ }^{11}$ Bambang Waluyo, 2002. Penelitian Hukum dalam Praktik, Sinar Grafika, Jakarta, Hlm. 8
}

penerapan hukum. Adapun keadaan yang digambarkan dalam penelitian ini adalah mengenai kolusi yang terjadi antara dokter dengan perusahaan farmasi dalam meresepkan obat sehingga mengganggu profesionalitas dokter yang dapat merugikan pasien.

Karena penelitian ini merupakan penelitian hukum normative, maka sumber hukum yang digunakan adalah:

a. Bahan Hukum Primer, yang terdiri dari aturan-aturan hukum nasional dan hukum internasional yang terkait dengan gratifikasi sebagai bagian dari tindak pidana korupsi serta peraturan terkait etika profesi dokter.

b. Bahan Hukum Sekunder, yaitu bahan yang memberikan penjelasan mengenai bahan hukum primer. $^{12}$ Bahan hukum sekunder berasal dari buku-buku teks yang berisi prinsipprinsip hukum dan pandanganpandangan hukum para sarjana. ${ }^{13}$

c. Bahan hukum tersier, merupakan bahan hukum yang memberikan petunjuk maupun penjelasan terhadap bahan hukum primer dan bahan hukum sekunder, ${ }^{14}$ antara lain: Kamus Terminologi Hukum, Kamus Bahasa Inggris, Kamus Besar Bahasa Indonesia, dan internet.

Metode pengumpulan data dilakukan dengan studi kepustakaan (library research), yaitu dengan cara mempelajari

\footnotetext{
Loc.Cit.

${ }^{13}$ Ronny Hanitijo, 1993, Metode Penelitian Hukum, Ghalia Indo, Jakarta, Hlm. 43

${ }^{14}$ Sorjono Soekanto, 2006. Penelitian Hukum Normatif, PT. RajaGrafindo Persada, Jakarta, Hlm. 61
}

2 Soerjono Soekanto dan Sri Mamudji, 
dan meneliti literatur yang berhubungan dengan permasalahan yang akan diuraikan. Menurut Rianto Adi, jika data yang diperlukan untuk menjawab masalah penelitian terdapat dalam bahan pustaka, maka kegiatan pengumpulan data itu disebut dengan literatur study. ${ }^{15}$

Selanjutnya, dilakukan pengolahan data. Pengolahan data adalah kegiatan merapikan hasil pengumpulan data, yaitu dengan cara menyeleksi atas dasar reabilitas dan validitasnya. ${ }^{16}$ Data-data tersebut disusun secara berurutan dan teratur sesuai dengan permasalahan.

Proses selanjutnya, data yang telah diinventarisasi dilakukan proses edditing, yaitu meneliti kembali terhadap catatancatatan, berkas-berkas, informasi yang dikumpulkan oleh pencari data yang diharapkan akan dapat meningkatkan mutu kehandalan (reabilitas) yang hendak dianalisis. ${ }^{17}$ Hal ini bertujuan untuk mendeteksi kesalahan-kesalahan, kemudian memperbaikinya, sehingga diperoleh data yang berkualitas.

Analisis data yang digunakan penulis dalam penelitian ini adalah metode analisis kualitatif, yaitu analisis yang dilakukan tidak dengan menggunakan angka-angka atau rumus statistik, melainkan dengan menggunakan kata-kata atau uraian kalimat dengan melakukan penilaian berdasarkan peraturan perundangundangan, teori atau pendapat ahli, serta

15 Rianto Adi, 2004. Metodologi Penelitian Sosial dan Hukum, Granit, Jakarta, Hlm. 72

16 Sumardi Suryabrata, 2006. Metodologi Penelitian, PT. Raja Grafindo Persada, Jakarta, Hlm. 40

${ }^{17}$ Amiruddin dan Zainal Asikin, Op.Cit, Hlm. 168-169 logika sehingga dapat ditarik kesimpulan yang logis dan merupakan jawaban dari permasalahan. Kemudian penulis juga menggunakan analisis isi (content analisis) yaitu teknik apapun yang digunakan untuk menarik kesimpulan melalui usaha menemukan karakteristik pesan dan dilakukan secara objektif dan sistematis. ${ }^{18}$

\section{HASIL DAN PEMBAHASAN}

Untuk mencegah terjadinya kolusi perusahaan farmasi dan dokter dalam pemasaran obat ini, sudah sangat banyak dilahirkan aturan-aturan dan kode etik yang mengikat bagi profesi dokter.

Pertama, Kewajiban umum yang melekat pada profesi dokter telah dituangkan dalam Pasal 3 Kode Etik Kedokteran (KODEKI) Hasil Mukernas Etik Kedokteran III Tahun 2001 sebagai pedoman etik bagi dokter dalam menjalankan profesi kedokteran. Pasal 3 KODEKI menyebutkan bahwa dalam melakukan pekerjaan kedokterannya, seorang dokter tidak boleh dipengaruhi oleh sesuatu yang mengakibatkan hilangnya kebebasan dan kemandirian profesi.

Penjabaran tentang perbuatan yang dipandang bertentangan dengan etik kedokteran ditemukan dalam Penjelasan Pasal 3 KODEKI, yaitu terdiri atas:

1. Secara sendiri atau bersama-sama menerapkan pengetahuan dan keterampilan kedokteran dalam segala bentuk.

${ }^{18}$ Soejono dan Abdurrahman, 2003. Metode Penelitian Hukum, Rineka Cipta, Jakarta, Hlm. 16 
Yenny Fitri. Z: Tinjauan Hukum Dokter Yang Berkolusi Dengan Perusahaan Farmasi ...

2. Menerima imbalan selain dari pada yang layak, sesuai dengan jasanya, kecuali dengan keikhlasan dan pengetahuan dan atau kehendak pasien.

3. Membuat ikatan atau menerima imbalan dari perusahaan farmasi/obat, perusahaan alat kesehatan/kedokteran atau badan lain yang dapat mempengaruhi pekerjaan dokter.

4. Melibatkan diri secara langsung atau tidak langsung untuk mempromosikan obat, alat atau bahan lain guna kepentingan dan keuntungan pribadi dokter.

Kedua, pada tahun 2002 Badan Pengawas Obat dan Makanan (BPOM) juga telah menerbitkan Surat Keputusan (SK) Kepala BPOM Nomor HK.00.05.3.02706 tentang Promosi Obat. Bab V Pasal 8 SK Kepala BPOM menyebutkan setiap pemberian dan donasi yang akan diberikan oleh Industri Farmasi dan/atau Pedagang Besar Farmasi, tidak boleh dikaitkan dengan penulisan resep atau anjuran penggunaan obat yang bersangkutan. Kemudian yang tidak kalah pentingnya, pemberian dan donasi tersebut hanya diperbolehkan untuk diberikan kepada institusi, tidak kepada pribadi profesi kesehatan.

\section{Ketiga, International Pharmaceutical} Manufacturers Group (IPMG), sebuah asosiasi beranggotakan 24 perusahaan farmasi berbasis penelitian internasional yang beroperasi di Indonesia. Semua anggota IPMG menjunjung tinggi kepatuhan terhadap peraturan dan hukum terkait, khususnya kode etik dalam praktik pemasaran. Pinsip-prinsip utama yang dipegang dalam kode etik IPMG tersebut, antara lain semua kegiatan promosi harus demi kepentingan dan keuntungan pasien, meningkatkan kualitas layanan medis melalui pemberian informasi yang akurat untuk penggunaan yang tepat, menjaga independensi profesi kesehatan, serta berupaya agar semua perusahaan farmasi sesama anggota IPMG bersaing secara adil dan beretika dalam memasarkan obat produksinya. ${ }^{19}$

Keempat, Peraturan Menteri Kesehatan Nomor 14 tahun 2014 tentang Pengendalian Gratifikasi di Lingkungan Menteri Kesehatan yang mengatur tentang larangan penerimaan atau gratifikasi. Gratifikasi dalam Peraturan Menteri Kesehatan Nomor 14 tahun 2014 itu dibagi atas gratifikasi yang dianggap suap dan gratifikasi yang tidak dianggap suap. Gratifikasi yang dianggap suap dijelaskan pada Pasal 4 yaitu, penerimaan yang tidak terbatas: a) marketing fee atau imbalan yang bersifat transaksional dan terkait dengan pemasaran suatu produk; b) cashback yang diterima instansi digunakan untuk kepentingan pribadi; c) gratifikasi yang terkait pelayanan barang dan jasa, pelayanan publik dan lainnya; d) sponsorship yang terkait pemasaran dan penelitian suatu produk. Sedangkan, gratifikasi yang tidak dianggap suap diatur dalam Pasal 5 yaitu, pemberian secara resmi dari aparatur kementerian sebagai wakil resmi instansi dalam suatu kegiatan dinas sebagai bentuk penghargaan, atas

\footnotetext{
${ }^{19}$ Terdapat pada Kata Pengantar Kode Etik IPMG Tentang Praktik Pemasaran Produk Farmasi Revisi Juli 2013
} 
keikutsertaan kontribusi dalam kegiatan tersebut. Misalnya, pemberian berupa cindera mata dalam kegiatan resmi, Kedinasan seperti rapat, seminar, workshop, konferensi, pelatihan atau kegiatan lain sejenis. Kemudian, kompensasi yang diterima terkait kegitaan kedinasan, seperti honorarium, transportasi, akomodasi dan pembiayaan sebagaimana diatur pada standar biaya yang berlaku instansi pemberi, sepanjang tidak ada pembiayaan ganda, nilai tak wajar, tidak terdapat konflik kepentingan, tidak melanggar ketentuan yang berlaku di instansi penerima.

Dari empat uraian di atas terlihat bahwa sudah banyak aturan yang mengatur bahwa dokter dilarang menerima pemberian dalam bentuk apa pun dari pihak lain yang dapat mempengaruhi profesionalitasnya dalam memberikan pelayanan kesehatan kepada pasien. Dengan adanya pemberian dari perusahaan farmasi, membuat dokter tidak lagi meresepkan obat atas pertimbangan penyakit pasien semata, melainkan karena adanya kepentingan pribadi demi memenuhi kesepakatan dengan perusahaan farmasi. Dampak dari kolusi dokter dan perusahaan farmasi ini menyebabkan harga obat menjadi tinggi, karena perusahaan farmasi membebankan biaya insentif dan pemberian untuk dokter tersebut kepada pasien dengan cara menaikkan harga obat yang akan ditebus pasien dari harga yang seharusnya.

Namun, kolusi yang tercipta antara dokter dan perusahaan farmasi ini sangat sulit untuk dibuktikan oleh pasien karena minimnya pengetahuan pasien atas penyakitnya dan pengobatannya. Sehingga tidak heran, meskipun praktek seperti ini sudah sering terjadi, tapi pasien yang merasa dirugikan lebih memilih untuk tidak lagi menggunakan jasa pengobatan dengan dokter tersebut daripada menempuh jalur hukum. Akibatnya, praktek kerjasama dokter dan perusahaan farmasi ini terus berlanjut tanpa ada solusi hukum untuk menghentikannya.

Beranjak dari temuan Tim Infestigasi Majalah Tempo atas pemberian sejumlah uang dan bonus oleh PT. Interbat terhadap tenaga dokter dalam meresepkan obat tersebut, muncul pemikiran bahwa dokter yang menerima pemberian dari perusahaan farmasi dapat dipidana sesuai aturan Undang-Undang Nomor 31 Tahun 1999 junto Undang-Undang Nomor 20 Tahun 2001 tentang Pemberantasan Tindak Pidana Korupsi atau disingkat UU Anti Korupsi.

Dalam UU Anti Korupsi, rumusan Tindak Pidana Korupsi selalu diawali dengan kata "barangsiapa" sebagai penunjuk subjek hukumnya. Rumusan tentang subjek hukum ini, mengacu pada Pegawai Negeri dan Penyelenggara Negara. Dengan demikian, untuk kasus dokter Pegawai Negeri bisa dikenakan ketentuan tentang gratifikasi. Pengaturan tentang gratifikasi diatur dalam Pasal 12B Undang-Undang Nomor 31 Tahun 1999 junto Undang-Undang Nomor 20 Tahun 2001 Tentang Pemberantasan Tindak Pidana Korupsi atau yang disingkat dengan Undang-Undang Anti Korupsi, yang berbunyi: 
Yenny Fitri. Z: Tinjauan Hukum Dokter Yang Berkolusi Dengan Perusahaan Farmasi ...

(1) Setiap gratifikasi kepada pegawai negeri atau penyelenggara negara dianggap pemberian suap, apabila berhubungan dengan jabatannya dan berlawanan dengan kewajiban atau tugasnya, dengan ketentuan sebagai berikut:

a. Yang nilainya Rp.10.000.000,00 (sepuluh juta rupiah) atau lebih, pembuktian bahwa gratifikasi tersebut bukan merupakan suap dilakukan oleh penerima gratifikasi;

b. Yang nilainya kurang dari Rp.10.000.000,00 (sepuluh juta rupiah), pembuktian bahwa gratifikasi tersebut siap dilakukan oleh penuntut umum.

(2) Pidana bagi pegawai negeri atau penyelenggara negara sebagaimana dimaksud dalam ayat (1) adalah pidana penjara seumur hidup atau pidana penjara paling singkat 4 (empat) tahun dan paling lama 20 (dua puluh) tahun, dan pidana denda paling sedikit Rp.200.000.000,00 (dua ratus juta rupiah) dan paling banyak Rp. 1.000.000.000,00 (satu milyar rupiah).

Menurut Yopie Morya Immanuel Patiro dalam bukunya Diskresi Pejabat Publik dan Tindak Pidana Korupsi, Tindak Pidana Korupsi menurut pengaturan UU Anti Korupsi terbagi atas korupsi aktif dan korupsi pasif. Korupsi aktif atau tindak pidana korupsi positif adalah tindak pidana yang dalam rumusannya mencantumkan unsur perbuatan aktif, sedangkan korupsi pasif atau tindak pidana korupsi negatif adalah tindak pidana yang dalam rumusannya mencantumkan perbuatan pasif. $^{20}$ Dalam UU Anti Korupsi,

20 Yopie Morya Immanuel Patiro, 2012, "Diskresi Pejabat Publik dan Tindak Pidana Korupsi”, Keni Media, Bandung, Hlm. 131 gratifikasi termasuk korupsi pasif atau tindak pidana korupsi negatif.

Menurut mantan Wakil Ketua Komisi Pemberantasan Korupsi, Johan Budi S.P, uang yang diterima dokter dari perusahaan farmasi dapat dikategorikan sebagai gratifikasi jika memenuhi beberapa unsur di antaranya dokter yang menerima uang dari perusahaan farmasi tersebut berstatus sebagai pegawai negeri atau penyelenggara negara. ${ }^{21}$ Namun jika di lihat, rumusan Pasal 12B UU Anti Korupsi memiliki rumusan yang hampir sama dengan Pasal 5 Ayat (2) UU Anti Korupsi tapi dengan penjatuhan sanksi yang berbeda. Jika melanggar ketentuan Pasal 12B UU Anti Korupsi dikenakan pidana seumur hidup atau pidana penjara paling singkat 4 tahun dan paling lama 20 tahun, dan pidana denda paling sedikit dua ratus juta rupiah dan paling banyak satu milyar rupiah. Sementara rumusal Pasal 5 Ayat (2) UU Anti Korupsi penjatuhan sanksinya adalah pidana penjara paling singkat 1 tahun dan paling lama 5 tahun dan/ atau pidana denda paling sedikit lima puluh juta dan paling banyak dua ratus lima puluh juta rupiah.

Jika kedua rumusan dalam Undangundang Anti Korupsi ini tidak segera diperbaiki, maka akan menimbulkan perbedaan Jaksa dalam memberikan tuntutan dan Hakim dalam menjatuhkan putusan terhadap dokter pegawai negeri yang menerima pemberian dari Perusahaan Farmasi.

${ }^{21}$ http://nasional.tempo.co/read/news/2015/11/ 04/173715783/ekslusif-suap-obat-kpk-itugratifikasi-jika. Diunduh Jum'at, 16 Februari 2018 Pukul 17.30 Wib. 
Satu permasalahan terkait dokter Pegawai Negeri yang menerima pemberian dari Perusahaan Farmasi sudah bisa dipidana sesuai dengan UU Anti Korupsi. Namun seperti yang sudah disebutkan dari awal, selain berstatus dokter Pegawai Negeri, profesi dokter juga ada yang berstatus sebagai dokter swasta yang membuka tempat praktek mandiri.

Sistem Hukum Pidana Indonesia membedakan antara "Public Official Bribery" dan "Private Briberry". "Public Official Bribery" maksudnya jika para pelaku baik penerima maupun pemberi suap adalah pegawai negeri, sedangkan "Private Briberry" jika pelakunya adalah pihak swasta. ${ }^{22}$ Jika dokter yang berstatus pegawai negeri bisa dikenakan pengaturan gratifikasi atas pemberian yang diterimanya dari perusahaan farmasi, tentu dokter swasta pun harus diberlakukan juga aturan pidana jika melakukan hal yang sama. Tapi jika merujuk pada aturan tentang gratifikasasi, dokter swasta tidak termasuk dalam unsur di dalamnya. Solusinya, bagi dokter swasta yang menerima pemberian dari perusahaan farmasi dengan maksud untuk mempengaruhinya dalam meresepkan obat kepada pasien, bisa dikenakan Pasal 3 Undang-Undang Nomor 11 Tahun 1980 Tentang Tindak Pidana Suap atau yang disingkat Undang-Undang Anti Suap yang berbunyi:

"Barang siapa menerima sesuatu atau janji, sedangkan ia mengetahui atau patut dapat menduga bahwa

22 Indriyanto Seno Adji, 2009, Korupsi Kebijakan paratur Negara dan Hukum Pidana", C.V Diadit Media, Jakarta, Hlm. 306 pemberian sesuatu atau janji itu dimaksudkan supaya ia berbuat sesuatu atau tidak berbuat sesuatu dalam tugasnya, yang berlawanan dengan kewenangan atau kewajibannya yang menyangkut kepentingan umum, dipidana karena menerima suap dengan pidana penjara selama-lamanya 3 (tiga) tahun atau denda sebanyakbanyaknya lima belas juta rupiah”.

Dengan adanya pengaturan dalam Pasal 3 Udang-Undang Nomor 11 tahun 1980 ini, maka dokter swasta yang menerima pemberian dari perusahaan farmasi juga dapat dikenakan pidana. Pengaturan pemberian kepada dokter oleh Perusahaan Farmasi pada UU Anti Suap memiliki perbedaan yang jelas dibandingkan pengaturan dalam UU Anti Korupsi. Perbedan tersebut melingkupi: ${ }^{23}$

1. Undang-Undang Anti Suap hanya berkaitan dengan perbuatan yang dinamakan "private bribery", sehingga tidak memiliki persyaratan pada "public official bribery" seperti hubungan antara kekuasaan dengan jabatan seperti rumusan yang ada dalam Uundang-Undang Anti Korupsi.

2. Kepentingan umum atau "public intersest" merupakan syarat yang melekat pada Uundang-Undang Anti Suap yang tidak ditemukan dalam Uundang-Undang Anti Korupsi.

Dengan dasar tersebut, dokter swasta yang menerima pemberian dari Perusahaan Farmasi yang belum terakomodir oleh Uundang-Undang Anti Korupsi, bisa dijatuhkan pidana sesuai dengan UundangUndang Anti Suap.

\footnotetext{
${ }^{23}$ Ibid, Hlm. 308
} 
Yenny Fitri. Z: Tinjauan Hukum Dokter Yang Berkolusi Dengan Perusahaan Farmasi ...

\section{SIMPULAN}

Berdasarkan hasil penelitian, analisa dan pembahasan yang telah dilakukan maka dapat disimpulkan bahwa dokter yang menerima pemberian dari perusahaan farmasi dapat dikenakan pidana. Hal ini tujuannya untuk mencegah terjadinya kolusi antara dokter dengan perusahaan farmasi agar tidak merugikan pasien dalam menerima resep obat dan mendapatkan pelayanan kesehatan. Bagi dokter swasta yang menerima pemberian dari perusahaan farmasi dapat dikualifikasikan sebagai Tindak Pidana Suap yang diatur dalam Pasal 3 Undang-Undang Nomor 11 Tahun 1980 (UU Anti Suap), sedangkan bagi dokter pegawai negeri dapat dikualifikasikan sebagai Tindak Pidana Gratifikasi yang diatur dalam Pasal 12B Undang-Undang Nomor 31 Tahun 1999 junto Undang-Undang Nomor 20 Tahun 2001 Tentang Pemberantasan Tindak Pidana Korupsi (Undang-Undang Anti Korupsi).

Beranjak dari hasil penelitian tersebut, maka Penulis mengemukakan sejumlah saran sebagai berikut:

1. Rumusan Pasal 12B Undang-Undang Anti Korupsi diperluas. Jika saat ini Pasal 12B Undang-Undang Anti Korupsi mengatur "Setiap gratifikasi kepada pegawai negeri atau penyelenggara negara dianggap pemberian suap, apabila berhubungan dengan jabatannya dan berlawanan dengan kewajiban atau tugasnya..." diganti dengan rumusan yang berbunyi "Setiap gratifikasi dianggap pemberian suap, apabila berhubungan dengan jabatannya dan berlawanan dengan kewajiban atau tugasnya...". Dengan demikian, rumusan pasal 12B tersebut juga dapat menjerat profesi lain dan tidak terbatas hanya kepada pegawai negeri atau penyelenggara negara semata.

2. Sambil menunggu perluasan rumusan Pasal 12B Undang-Undang Anti Korupsi, penegak hukum dapat berperan aktif dengan menggunakan Pasal 3 Undang-Undang Anti Suap untuk menjerat dokter yang menerima pemberian dari perusahaan farmasi. Sehingga bisa menutup celah hukum yang selama ini terjadi.

\section{UCAPAN TERIMA KASIH}

Segala puji dan syukur penulis ucapkan atas Rahmad Allah SWT yang telah memberikan kemudahan dalam menyelesaikan penulisan yang berjudul "Tinjauan Hukum Dokter yang Berkolusi dengan Perusahaan Farmasi dalam Meresepkan Obat". Shalawat dan salam pun tercurah kepada Nabi Muhammad SAW, manusia mulia yang menjadi pedoman manusia hingga akhir zaman.

Banyak pihak yang ikut berpartisipasi membantu penulis dalam penelitian karya ini. Untuk itu, Penulis ingin mengucapkan terima kasih kepada:

1. Bapak Dr. Eviandi Ibrahim S.H., M.Hum selaku Ketua Sekolah Tinggi Ilmu Hukum Putri Maharaja Payakumbuh

2. Seluruh rekan-rekan Dosen Sekolah Tinggi Ilmu Hukum Putri Maharaja 
yang tidak dapat penulis sebutkan satu-persatu.

\section{DAFTAR PUSTAKA}

\section{Buku}

Amiruddin dan Zainal Asikin, th, Pengantar Metode Penelitian Hukum, PT. Raja Grafindo Persada, Jakarta.

Bambang Waluyo, 2002. Penelitian Hukum dalam Praktik, Sinar Grafika, Jakarta.

Indriyanto Seno Adji, 2009, Korupsi Kebijakan paratur Negara dan Hukum Pidana", C.V Diadit Media, Jakarta.

Mestika Zed, 2007, Metode Penelitian Kepustakaan, Yayasan Obor Indonesia, Jakarta.

Rianto Adi, 2004. Metodologi Penelitian Sosial dan Hukum, Granit, Jakarta.

Ronny Hanitijo, 1993, Metode Penelitian Hukum, Ghalia Indo, Jakarta.

Soejono dan Abdurrahman, 2003. Metode Penelitian Hukum, Rineka Cipta, Jakarta.

Soerjono Soekanto dan Sri Mamudji, 2010, Penelitian Hukum Normatif Suatu Tinjauan Singkat, Rajawali Pers, Jakarta.

Soerjono Soekanto, 1986. Pengantar Penelitian Hukum, UII Press, Jakarta.

Sorjono Soekanto, 2006. Penelitian Hukum Normatif, PT. Raja Grafindo Persada, Jakarta.

Sumardi Suryabrata, 2006. Metodologi Penelitian, PT. Raja Grafindo Persada, Jakarta.
Yopie Morya Immanuel Patiro, 2012, "Diskresi Pejabat Publik dan Tindak Pidana Korupsi”, Keni Media, Bandung.

\section{Internet}

http://nasional.tempo.co/read/news/2015/1 1/11/173717860/gratifikasi-doktermenteri-nila-akan-temui-farmasidan-idi

http://www.kpk.go.id/id/berita/beritasub/3067-menteri-kesehatangandeng-kpk-cegah-gratifikasidokter

http://nasional.tempo.co/read/news/2015/1 1/04/173715783/ekslusif-suap-obatkpk-itu-gratifikasi-jika.

\section{Peraturan Perundang-Undangan}

Undang-Undang Republik Indonesia Nomor 36 Tahun 2014 tentang Tenaga Kesehatan.

Kode Etik Kedokteran

Etik IPMG Tentang Praktik Pemasaran Produk Farmasi Revisi Juli 2013

Rencana Pembangunan Jangka Panjang Nasional 2005-2025. 